\title{
The Early English Passion Play
}

Pamela M. King

\begin{abstract}
:
This essay challenges the common understanding that biblical drama in England was dominated by "mystery plays", as narrowly understood to be cycles of short pageants, by drawing attention to the evidence for large scale Passion Plays comparable with those better known from France and Burgundy. In so doing, it makes no apology for standing on the shoulders of Peter Meredith's work on the N.town manuscript, and with John Tailby on the texts and documents illustrating the variety of staging of religious drama across Europe, as well as Meg Twycross's work on devisor Felsted of London, all of which demonstrate that this material has been available in the public domain for some years. Just as the N.town Plays were still believed in some quarters to come from Coventry as late as the mid-twentieth century, although Francis Douce knew they did not almost 150 years earlier, so too, the domination of modern understandings about English mystery plays has remained wedded to the model of four "cycles" promulgated in the 1970s despite the accumulation of evidence to the contrary. Peter Meredith's edition of The Passion Play from the N.town Manuscript is now all but unobtainable, and the volumes of Records of Early English Drama are the chosen bedtime reading of few, so here we revisit some texts and records to explore afresh one aspect of an already-shifted paradigm.
\end{abstract}

It is tenaciously assumed, despite much of the work done in the field in the last thirty years, that 'mystery plays' prevail as the major form of medieval biblical drama in the English tradition, and that these are cycles of short pageants mounted on processional wagons that tell the story of the world from Creation to Doomsday such as those from York and Chester. ${ }^{1}$ The auspices of English 'mystery plays' thus defined are not only about ambitious chronology, but infer a certain style of dramaturgy that is episodic, and characterized by economies of on-scene movement, both characteristics reflecting the exigencies of wagon performance.

Common understanding also has it that, while England favoured the Corpus Christi cycle, the French favoured Passion plays. In fact the French seem to use the terms passion and mystère interchangeably or, as in Le mystère de la Passion Nostre Seigneur (1131), together. ${ }^{2}$ Even once

\footnotetext{
${ }^{1}$ This position is reinforced by the continuing popularity of Rosemary Woolf's influential and detailed study, The English Mystery Plays (London: Routledge and Kegan Paul, 1972), which pre-dates the work of the Records of Early English Drama project which has incrementally revealed the variety of religious drama in England, but see also Wikipedia, http://en.wikipedia.org/wiki/Mystery_play [accessed 24/09/2012]; Answers.com, http://www.answers.com/topic/mystery-play [accessed 24/09/2012].

${ }^{2}$ Le mystère de la Passion Nostre Seigneur, edited by Graham A. Runnalls (Paris and Geneva: Librairie Minard / Librairie Droz, 1974)
} 
we dispose of the false etymology that long connected "mystery" with "guild" where the plays are concerned, the pan-European use of the term "mystery" and its variants is more permissive than the insular understanding outlined above, referring to any drama that enacts the revelation of religious truth. ${ }^{3}$ The late Graham Runnalls describes all the 230 surviving French medieval religious plays as "mystères”. The Passions form a major subset, and Eustache Marcadé's (d.1440) four-day Passion d'Arras, the Passion of Arnoul Gréban (1455) which follows the model of Marcadé's, and the two Passions from Valenciennes (1547), derived from Gréban and famous for their set designs, dominate the study of French medieval drama in the way that the cycles of York and Chester conventionally have the English. ${ }^{4}$

A second look at the English material, however, unsurprisingly, gives a more fluid and complicated picture than the simple division into processional Creation to Doom cycles as the dominant form, in contradistinction to the French Passion which was more restricted in subject matter but more expansive in its amphitheatrical staging. It is well known that in Coventry, where the two surviving pageants and the extensive records datefrom the mid sixteenth century, there is no evidence of any Old Testament subjects, and the lost Smiths' pageant appears to have covered much of the material of a Passion play within a single pageant. ${ }^{5}$ Then there is the massive Ordinalia from Cornwall, performed in the round and devoting the whole of its second of three days of performance to the Passion. ${ }^{6}$ This essay seeks to open the exploration of the evidence that England too had its tradition of Passions in the pure 'French' understanding of the genre that deserve attention not as truncated or variant mystery cycles, but as representing a distinct native dramaturgy.

Our starting point is necessarily Peter Meredith's important critical edition of The Passion Play from the N.town Manuscript. ${ }^{7}$ It is unnecessary to rehearse here more than briefly the codicological evidence which led Meredith to conclude that buried within British Library Cotton Vespasian D. VIII, not a cycle but a compilation project, is a two-part Passion play. The first part is bound into the manuscript as a separate booklet, numbered as pageants twenty-five to twenty-seven, dealing with the events from the beginning of the conspiracy to Christ's arrest. Interpolated into it are two sections of what Meredith believes were originally pageants, but he concludes that the form of Passion Play 1 is largely clear, if unfinished. ${ }^{8}$ The second Passion

\footnotetext{
${ }^{3}$ See further Introduction above p.**

${ }^{4}$ Graham A. Runnalls, "Gréban, Arnoul” in The New Oxford Companion to Literature in French, edited by Peter France, (Oxford: Oxford University Press, 1995), at http://www.answers.com/topic/arnoul-gr-ban (accessed 3 August, 2012) and Graham A. Runnalls, Les Mystères français imprimés (Paris: Honoré Champion, 1999), pp. 17885. The Valenciennes set design is reproduced in Luminarium: Anthology of English Literature, at http://www.luminarium.org/medlit/medievaldrama.htm[accessed 24/09/2012]

${ }^{5}$ See The Coventry Corpus Christi Plays, edited by Pamela M. King and Clifford Davidson (Kalamazoo MI: Medieval Institute Publications, 2000), especially pp. 29-33.

${ }^{6}$ See Brian O. Murdoch, "The Cornish Medieval Drama” in The Cambridge Companion to Medieval English Theatre, edited by Richard Beadle, $1^{\text {st }}$ Edition (Cambridge: Cambridge University Press, 1994), pp.211-39, pp. 21624.

${ }^{7}$ Peter Meredith, ed., The Passion Play from the N.town Manuscript (London and New York: Longman, 1990).

${ }^{8}$ Meredith, Passion Play, pp. 4-8. For the interpolations see further Appendices 1 and 2, pp. 229-41. To follow the codicological arguments in the edition, see further Peter Meredith and Stanley J. Kahrl, The N-Town Plays, $a$
} 
play, breaking off with Christ's appearance to Mary Magdalen after the Resurrection, also shows the signs of beinga separate play, although in the manuscript context it is much more disrupted, and cannot be as easily detached as Passion 1 . The 'banns' at the beginning of the manuscript offer inaccurate descriptions of the material in both parts of the play, giving prominence to the pageant material, thus further suggesting that the text as a whole is in transition. ${ }^{9}$ The incomplete adaptation of the material into a coherent whole is, however, fortunate in that the scribe has failed to efface entirely traces of the plays' original form. For example Passion 1 opens with an end fragment of a procession which seems to have opened the free-standing play, and the prologue to Passion 2 refers to events played in 'be last zere' (1.6).

More recently, the editor of the Records of Early English Drama volume for Kent made accessible the extraordinary Passion Plays, known to Meredith, ${ }^{10}$ and performed annually in New Romney as a co-operative venture undertaken by the town itself and a number of surrounding villages. These records go back to a point in the fifteenth century closely contemporary with N.Town, and are complemented then by more detailed documents from the mid sixteenth century, continuing until 1568. ${ }^{11}$ The evidence requires careful handling: a fragment of a playwarden's account from the 1480s is unlikely to relate closely to the performance that may be adduced from a variety of documents from the 1560s. Equally, the existence of the N.Town text without context, and the New Romney context without text must not be allowed to generate certainties out of tunnel-vision; indeed lurking in the Essex records, John Coldewey discovered in the years before REED, evidence of a play put on in Maldon, assisted by neighbouring communities, which hints at a similar enterprise, and there may be more. ${ }^{12}$ It is thus, as ever, upon a fundamentally problematic evidence base that the following tentative attempt at a taxonomy of the English Passion Play will be based.

After two Prologues, the action of N.Town Passion Play 1 opens with the assembling of the conspirators, before moving on to dramatise the Entry into Jerusalem. The progress towards Jerusalem is interrupted by the invitation to attend the house of Simon the Leper, where the Last

facsimile of BL MS Cotton Vespasian D VIII, Leeds Texts and Monographs, Medieval Drama Facsimiles 4 (Leeds: University of Leeds, 1977), pp. xiii-xiv.

${ }^{9}$ Meredith, Passion Play, pp. 8-9, 245-50.

${ }^{10}$ The Staging of Religious Drama in Europe in the Later Middle Ages: Texts and Documents in English Translation, edited by Peter Meredith and John E. Tailby (Kalamazoo, MI: Medieval Institute Publications, 1983), 27, 42, 60, 142.

${ }^{11}$ Records of Early English Drama: Diocese of Canterbury. Kent, edited by James M. Gibson (Toronto: Toronto University Press, 2002), pp. lix-lxiv, 738-94, 1183-1208.

12 John C. Coldewey, 'Early Essex Drama: a History of its Rise and Fall, and a Theory concerning the Digby Plays', unpublished PhD thesis, Department of English, University of Colorado, 1972, pp. 53-60, 261-84. I am grateful to Alexandra F. Johnston for drawing my attention to these records. 
Supper and foot-washing take place. While Jesus is going to the House of Simon the Leper, Judas enters and strikes his bargain with the gathered conspirators. Then Simon's house opens to reveal the Last Supper. After the Last Supper and the foot-washing sequence, Jesus departs with the disciples for Bethany, stopping at Mount Olivet where the Agony in the Garden is performed before the conspirators arrive, Judas identifies Jesus, Peter cuts off Malchus’s ear, Jesus is arrested and carried off, and the play ends with Mary Magdalen fetching the Virgin Mary who delivers the first of her extended laments.

This summary gives little of the flavour of the action that is conveyed by the spoken script and, in particular its stage directions. In the opening sequence, Annas, on his scaffold, takes advice from his doctors who then go out to seek two judges, Refyn and Lyon. A messenger goes to Caiaphas, revealed on his own scaffold, and he agrees to the trial. Rewfyn and Lyon show themselves in another place, then all process to converge in 'pe myd place; and per xal be a lytil oratory with stolys and cusshonys clenly beseyn, lych as it were a cownsel hous’ (s.d. after l. 288). Immediately this sequence establishes many things about the use of space in this play, and already it seems incredible that it should have been read as a pageant in view of its evident expansive and multi-locational action.

In the following action the citizens of Jerusalem set out barefoot and carrying their gowns which they put down for Jesus to walk on, and, all kneeling, cry to him for mercy (s.d. after l. 406). They are accompanied by singing children who scatter flowers (s.d. after 1. 410). In his progress towards them from the opposite direction, Jesus cures two blind men, before being deflected to the house of Simon the Leper, whom they meet on the way carrying water. As Simon leads Jesus home, the disciples have to double back to meet him and accompany him. The movement, across the set and from event to event, continues to be briskly paced.

The Last Supper will occur in Simon’s house, but before it opens to reveal the customary tableau, the council house 'xal sodeynly onclose schewyng be buschopys, prestys and jewgys syttyng in here astat lych as it were a convocacyon’ (s.d. after l. 518). Thus action moves to focus on two oppositional 'houses', which are going to be linked by the next movement. At this point Judas comes into the place and addresses the audience directly. He then goes to the Council House and strikes his bargain, before departing in search of Jesus. The stage direction reads, 'Here Judas goth in sotylly wher-as he cam fro' (s.d. after 1. 650), but in fact he must get himself into Simon's house for the next scene. Audience attention is deflected to watch the judges 
disperse in preparation for the arrest, each going back to his personal scaffold to assemble his “meny”. All movement then stops as now 'xal pe place peer Cryst is in sodeynly vnclose rownd abowtyn, shewyng Cryst syttyng at pe table and hese dyscypulys ech in ere degree...' (s.d. after l. 662) Various events have competed for the audience's gaze in the preceding actions, but at this moment, the stage direction indicates that all eyes are drawn to the single location of the Last Supper.

Thus far, the play has had an expansiveness of movement that no pageant can have. Much of that movement is redundant in absolute terms, ${ }^{13}$ as characters meet and part, then meet again. Messengers scurry, but the main characters, lavishly dressed according to hints in the stage directions, most probably processed from place to place, their pace of movement mirroring their mode of speech, which often involves ceremonial address in the high style. The whole play reveals itself as designed for production on a grand scale, demanding that it fill its space and satisfy its audience with its scope. That space could be any shape, but the action suggests that it needs to be constantly occupied, and travelled through, as the cast works to embrace and engage a large audience.

The Last Supper sequence brings all the movement to rest for a time, but is expansive in different ways. Jesus’s speech, almost a hundred lines long (ll. 663-754), begins with an exposition of the Paschal Lamb in its Old Testament meaning, going on to define it as signifying the 'old lawe', and himself as the 'newe lomb, pat xal be sacryd be me' (ll.684-85). Then, in the following exposition of the Mass bread, he makes a series of contrived typological connections with the lamb of the Passover, before distributing the Mass to each disciple with the words,

This is my body, flesch and blode,

pat for pe xal dey upon pe rode. (1l.763-64)

Judas is omitted from this blessing and asked to bring to an end what he has begun.

At this point in the text there is an optional insertion, for as Judas departs to fetch the Jews the stage direction adds, 'and yf men wolne [the devil] xal mete with hym and sey pis speech folwyng - or levynt whether pei wyl...' (s.d. after l. 778). The devil’s speech contributes little to the meaning of the scene, he simply tells Judas to hurry up, and goes off to hHell to prepare a special place for him. It does, however, provide spectacle and counterpoint to punctuate the long sermon being preached by Jesus, so may have proved a shrewd insertion to

\footnotetext{
${ }^{13}$ As observed by Meredith, Passion Play, p. 25.
} 
distract restive elements in the audience who perhaps did not enjoy perfect sight-lines to the central tableau.

As Jesus consecrates the wine (1. 799), the stage direction indicates that the disciples leave their places to receive it, before returning to their seats again. We cannot really tell how the dramatist envisaged the disciples being grouped at the Supper; when the event is shown in the visual arts, the disciples are rarely seated all around a table, except on roof bosses, ${ }^{14}$ but are lined up along one side. As Rosemary Woolf pointed out, however, in Fra Angelico’s Last Supper the disciples stand in line waiting to receive the sacrament for which they kneel, underscoring the direct connection with the Mass. ${ }^{15}$ At the end of the distribution of the elements, Jesus further charges Peter and the others with the duty to conduct the priestly duty of administering the sacrament. He then washes the disciples’ feet before resuming his seat to tell them what is going to happen next.

The Last Supper sequence is perhaps closer in its procedures to the episodic cycle pageants than any other element of the play, and yet the elaborated preaching of the central character goes beyond anything a cycle dramatist has the time and space for. Whereas the Last Supper in York constructs, like many of the pageants, an affecting speaking picture, in this play the balance is fundamentally different, and the same episode is more a visually animated sermon.

Hereafter the play moves back into its pattern of constant and busy multi-locational movement. Once Christ and his disciples have arrived at Bethany, described as a little place like a park, the following Agony in the Garden sequence involves Jesus coming and going between the sleeping disciples and 'Olyvet' until 'an aungel descendyth to Jhesus and bryngyth to hym a chalys with an host perin' (s.d. after 1.936). It is a huge source of regret that in a play with so many detailed stage directions, there is no indication of where the angel comes from or goes to after delivering a brief speech putting Passion, institution of the Mass, priesthood, and the larger metaphysical meaning of events into the context of the Parliament of Heaven:

Heyl bothe God and man indeed!

The Fadyr hath sent pe pis present.

He bad pat pu xuldyst not drede,

\footnotetext{
${ }^{14}$ See for example the roof boss in Norwich Cathedral, illustrated at http://www.paradoxplace.com/Photo\%20Pages/UK/Britain_Centre/Norwich_Cathedral/Norwich.htm [accessed 24/09/2012].

${ }^{15}$ Woolf, English Mystery Plays, p. 233.
} 
But fulfylle his intent,

As pe parlement of hefne hath ment,

pat mannys sowle xal now redemyd be.

From Hefne to herd, lord, pou wore sent;

pat dede appendyth onto the.

pis chalys ys pi blood, pis bred is pi body,

For mannys synne evyr offeryd xal be

To pe Fadyr of heffne pat is almythty;

pi dysciplis and all priesthood xal offere fore the. (1l. 937-948)

The Parliament of Heaven, otherwise known as the Procès de Paradis, is a prominent element in the French Passions. An allegorized expansion of Psalm 84, it represents the process within the Godhead whereby the Incarnation is determined by the reconciliation of Truth and Righteousness with Mercy and Peace. Although it is not fully dramatised here, it forms a major and elaborate element in the N.Town Mary Play. We cannot assume any particular pre-existing relationship between the two plays, and the Parliament, being an anagogical event, can take place equally either before the Incarnation or before the Passion, as theologically it sits behind and as a gloss to either or both. What the angel's speech makes clear here, is simply that the dramatist, as in the Last Supper sequence, and more broadly in the whole N.Town collection, has ambitions of theological sophistication to match the sophistication of his mise-en-scene.

The subsequent arrest of Christ is then another moment of grand spectacle, as the arresting officers appear with a large retinue of armed men, presumably processing from their scaffolds even as the Agony sequence concludes. Then almost as a coda to the action, Mary Magdalen runs from the arrest to the Virgin Mary, thereby triggering the planctus (ll. 10451076), with its customary rhetorical alternations of apostrophe and questions directed at God, that concludes the play.

Contemplacio, the distinctive commentator throughout N.Town, opens Passion Play 2 with a synopsis of Passion 1, then Herod is revealed on his scaffold. His appearance is out of sequence as Christ has yet to appear before Annas and Caiaphas, and Pilate. However the continuous, multi-locational, overlapping action of these Passion Plays allows for him, like the Demon who opens Passion 1, to threaten the audience, and to reinforce proleptic foreboding of 
the coming action by suggesting that malign forces hover in the background, not only ranged against the protagonist but also viciously disposed toward him. He is easily put on hold, going to sleep to wait until he meets Christ. Action then explodes on to the scene with a Messenger who runs around the place with cries of 'Tydynges, tydynges!' and 'Jhesus of Nazareth is take!' (s.d after l. 89), before giving an eye-witness account of the arrest of Christ to Caiaphas and Annas (ll. 90-117). Consequently the continuation of the Passion narrative after a year's break (6) is set up by these three sequences - Contemplacio, Herod, the Messenger - as a sophisticated piece of dramatic writing that first engages the audience's attention, then engages them emotionally by using Herod to trigger anxiety and foreboding, then by leading them excitedly into the moment at which the action last broke off through the activity of the Messenger, revivifying the playing place. The relationship between action and audience is to be developed further, as they will be cast as a crowd, worked on by the players who use various devices to incite emotion, but also witnessing an 'on-stage’ crowd working itself up into a misdirected frenzy of emotion.

Jesus is now subjected to a violent buffeting with chanting that parodies the game of “Blind Man’s Buff” or “Hot Cockles”, ${ }^{16}$ while a woman enters the place and challenges Peter, who then denies Christ as predicted, punctuated by cock-crows. Caiaphas and Pilate exchange messengers, then, while the audience waits for Pilate to come to the "moot hall", Judas enters the place, speaks,

pan Judas castyth down pe mony and goth and hangyth himself. (s.d. after 1.257) Caiaphas’s subsequent remark that a night has passed (1. 258), indicates some unspoken preceding action, strongly suggesting that Judas’s hanging did take place in front of the audience, further complicating the competing claims for their attention. ${ }^{17}$

Jesus is now 'ledyn abowt pe place' (s.d. after 1.265) to be brought before Pilate, now in the moot hall. The ensuing sequence shifts the focus from action to rapid dialogue, as Pilate's desire to give Jesus a fair hearing is drawn out against pressure and threats from the Pharisees (ll.

\footnotetext{
${ }_{16}^{16}$ Meredith, Passion Play, p.197n.

17 There is nothing to suggest that Judas did not hang himself in front of the audience; the plans for the two-day Passion Play from Lucerne in 1583 contain a 'Judas Tree' as part of the set (see Staging of Religious Drama in Europe in the Later Middle Ages, edited by Meredith and Tailby, end papers); and the Coventry Smiths, responsible for the lost Passion pageant there in 1572 can be seen acquiring a coat of canvas, a pulley, an iron hook, and a noose for the hanging of Judas, then, in the following year, paying "Fawston" 4d. for hanging Judas and another 4d. for cock-crowing. The hanging mechanism was further refined by theatrical entrepreneur Thomas Massey in 1578 (see Records of Early English Drama: Coventry, edited by R.W. Ingram (Toronto: Toronto University Press, 1981), pp. 260, 265, 269, 285, 289.
} 
266-377). Pilate establishes that Jesus was born in Herod's jurisdiction whereupon Herod's scaffold re-opens to reveal him seated in state, and all the Jews except Annas and Caiaphas kneel before him (s.d. after 1. 377). The arrangement in the place allows here for a clear distinction to be made between the different types of authority before which Jesus is tried. Herod's ensuing speech indicates that he is reconciled with Pilate, curious to see miracles, but then angered when Jesus refuses to perform or speak. He sends him off to be scourged 'tyl he is all blody' (s.d. after l. 469): presumably here, and in the later scourging, whips dipped in pigs' blood or similar achieved the desired effect.

What follows is further more complicated action as Jesus, dressed in white, is again led about the place, while the Devil gives a long speech, creating for the audience striking visual counterpoint. The Devil speaks of his resentment at Jesus's failure to succumb to the Temptation, but asserts his continuing determination to ensnare him: "For al his barfot-goyng fro me xal he not skype" (1.509). The "barefoot-going" is a striking epithet that refers to Jesus's personal humility but is also, presumably, being enacted in the place simultaneously as it is spoken. However the Devil, already apprehensive about what may happen should he succeed, warns hell to prepare. He is answered from hell, according to a stage direction, confirming the presence of hell-mouth as part of the set, as is illustrated on all visual representations of place-and-scaffold staging. ${ }^{18}$ An anxious demon's voice 'off' sets the scene for Satan's visit to Pilate's wife in an attempt to prevent the Crucifixion. She is apparently concealed in some area of Pilate's scaffold, as the devil creeps in, causing her to rush out in her 'shert' carrying her 'kyrtle' and making a 'rewly noise'. She comes to Pilate 'leke a mad woman’ (s.d. after l. 543), and just as Pilate has sent her back to bed with soothing words, Jesus is brought before him again. One assumes that Satan, who does not reappear, slips out of the back of Pilate's scaffold to hellmouth, while the audience's attention is directed to Jesus's perambulations back in front of Pilate at the moot hall.

The final trial sequence is beautifully set up, with comings and goings, and repeated debate, to create the impression that Christ's fate really does hang in the balance anew, despite the knowledge of the foregone conclusion shared by performers and audience alike. Once sentence is pronounced, detailing the ensuing action in the manner of a capital sentence (II. 67996), Pilate goes back to his scaffold with Annas and Caiaphas while the rest of the Jews strip

\footnotetext{
${ }^{18}$ See, for example, the Valenciennes Passion, the Cornish Ordinalia, and the Lucerne Passion; illustrations referenced in fn 4, 6 and 17 above.
} 
Christ, bind him to the pillar, and scourge him once more. The stage directions which detail the scourging, crowning with thorns, and carrying of the Cross, indicate the iconic importance of these actions (s.d. after l. 698). Before the cavalcade arrives at the centre point of the playing place designated to be Calvary, two women prompt Jesus to give his address to the 'daughters of Jerusalem' (1l. 707-18), Simon of Cyrene reluctantly shares the carrying of the Cross (1l.727-38), and Veronica wipes Jesus' face with her kerchief (ll.739-46).

There are two distinct elements to the crucifying itself. First Christ is pulled down on to the Cross and nailed to it, with the customary indications, common in the visual arts of the period, that his body has to be stretched to meet ill-fitting bores (s.d after l. 746; 1l. 747-782). Midway through the process, the crucifying Jews dance round the Cross mocking Christ (s.d after l. 774). The Cross is finally ‘set up’ (l. 779). What happens thereafter, however, is distinctive to the elaborated nature of the Passion Play and to large-scale staging. Four or five 'commoners' assemble to look on (s.d. after 1. 786), and so the Jews force them to nail up the two thieves. It may be assumed that these are 'extras', though they could equally be audience members. The attaching of the thieves to their crosses marks another moment when the action moves from one focal area of activity to a number of simultaneous ones. While the commoners nail up the thieves, the Jews dice for Christ's coat and the three Marys arrive with John. The stage direction here is explicit:

Here pe sympyl men xul settyn up bese two crossys and hangyn up pe thevys be pe armys. And perwhylys xal pe Jewys cast dyce for his clothis, and fytyn and stryvyn. And in pe mene tyme xal Oure Lady come with thre Maryes with here and sen John with hem, setting hem down aside afore pe cros, Our Lady swuonyng and morning and leysere seyng... (s.d. after 1. 790 - my italics)

At some compositional layer - probably that of the original - we are witnessing a dramaturge who envisaged precisely where and how he wanted action to be arranged on set. He not only had a desire to include as many elements of the Passion story as he could, but took measured judgements about which elements of that narrative should be treated as single focal points of action, and which could be run together or in overlapping sequence. In a large amphitheatre the attention of all audience members would have been directed to the Crucifixion, which, like the Last Supper in Passion Play 1, presumably took place in the middle, whereas with 
simultaneous "lesser" events, differently located sectors of the audience would have had different pieces of action played close to them. Practised audience members could thus take steps to ensure that they located themselves close to a favourite piece of action and/or performer. Equally the play pushes the director towards blocking action such that there is something going on close by for everyone at some point. If we follow the perception psychologists in understanding the kinetics of looking, ${ }^{19}$ we can see how both Passion plays, with all their movement across the place and breaks into simultaneous action, kept the audience's gaze constantly shifting - now focusing on something happening in the middle of the place, now following a messenger ranging to and fro across the place, now distracted by an element of relatively minor action taking place very close to, or, equally, choosing to strain to see another element of minor action taking place on the other side of the place. The play thus demands very active viewing by its audience. Equally the ability to use this kind of setting to offer an inclusive but well-paced performance solves problems of sequencing of what gospel harmonies suggest were simultaneous events.

The following action, once Mary is in place at the base of the Cross, refocuses the audience back on the central area of playing, but again keeps the eye busy. Mary speaks her formal planctus (ll. 791-98), and Jesus speaks from up on the cross forgiving the Jews (ll. 799802), who continue to mock him from below (ll. 803-18). The two thieves talk to and fro with each other and with Christ at the upper level (ll. 815-830), so that from below then the Virgin Mary complains that Jesus is ignoring her (ll. 831-42). His attention turns to her as he commits her to the care of John (1l. 843-54). John and the Marys then depart and Pilate, Annas and Caiaphas reappear on the scene (s.d. after 1. 866). Pilate writes the board that is set above the Cross (s.d. after 1. 874). Then Jesus cries from the Cross, is offered the vinegar rod, and dies (ll. 881-920). The content here and throughout is part of the well-worn narrative, and we are not concerned here with the specifics of the dramatist's likely sources, thoroughly covered by Meredith; ${ }^{20}$ what is of note is the way in which that action is paced to keep the audience busy, yet drawn out because of the relatively expansive production time and the lavish use of space. This material has little more in common with processional pageants than that it happens to give dramatic treatment to bible stories in Middle English verse. If we consider the reception of the

\footnotetext{
${ }^{19}$ See, for example, Andy Clark, "Cognitive Complexity and the Semimotor Frontier" in Andy Clark and Naomi Eilan, eds.. Semi-motor Skills and Perception, Aristotelian Society Supplementary Volume 80 (1), 43-65 (p. 44).

${ }^{20}$ Meredith, Passion Play, pp. 19-22
} 
Crucifixion itself, we can see that the close-up in the restricted space of the street of York's "Behold mine head, mine hands and mine feet", ${ }^{21}$ taken from the Impropreria of Good Friday, is televisual, while the N.town Passion is cinematic.

From here on, there is little new to add, and the integration of the 'original' Passion Play into the N.town compilation becomes increasingly hard to disentangle. At line 993, however, the play incorporates a major coup du theatre, also depending on simultaneous action. Anima Christi appears and makes a long speech, referring to the sacramental nature of his body, still hanging on the Cross. There is no indication of where he comes from; logically he has been separated from the body of Christ since the moment of death. The body is not yet in the tomb, suggesting that Anima Christi has either been concealed inside whatever device is used for the base of the Cross since the play began, like Anima in The Castle of Perseverance, ${ }^{22}$ or that he materialises from an otherwise unmentioned heaven scaffold. What is particularly effective in the play's unusual ordering of events here. Anima Christi sets off towards hell-gates so that the Harrowing of Hell can commence in the shadow of the still-inhabited Cross (ll.993-1026). Subsequently, with the entombed body under guard, he emerges from hell leading Adam, Eve, Abraham, John the Baptist, 'et aljis', binds Belial and goes on to resuscitate his own body (l. 1368-s.d after l. 1439). Unfortunately there is no stage direction to indicate how this latter process, as theologically as it is theatrically challenging, was to be constructed. Other elements in the final sequences are worth noting as evidence of the quality of the underlying dramatic imagination: notably Longeus's sight is restored because Christ's blood runs down his arm and he wipes his eyes (s.d. after l. 1142)

What the records from New Romney add to a textual analysis of the N.Town is further intelligence about how we might envisage such an ambitious production being organised and produced. While the N.town Passion Play seems to have been split into two separate performances played a year apart, the New Romney play was rehearsed in Lent and produced on

\footnotetext{
${ }^{21}$ See The York Plays: a Critical Edition of the York Corpus Christi Play as recorded in British Library Additional MS 35290, edited by Richard Beadle, Vol. I, Early English Text Society, ss. 23 (Oxford: Oxford University Press, 2009), pp. 339-40.

22 'Mankyndeis bed schal be vndyr pe castel and per schal be sowle lye vndyr be bed tyl he schal ryse and pleye': see The Castle of Perseverance, in The Macro Plays, edited by Mark Eccles, Early English Text Society, 262 (Oxford: Oxford University Press, 1969), pp. 1-111, p. 1. This play, although not a biblical-historical narrative, not only has a staging diagram showing the organisation of scaffolds in the round, but includes a debate of the four daughters of God (ll. 3129-3649) which also bear comparison with the N.town play under discussion.
} 
four days spread across the summer between Whit and September. ${ }^{23}$ In the fifteenth century, New Romney was in steady economic decline. ${ }^{24}$ In the early Middle Ages, the more affluent south western end of the town had clustered around the harbour, while the south eastern end of the town depended on fishing, and faced the beach where the fishing fleet of smaller vessels was pulled up. The town now lies inland; in 1468-71, booms were being set up across the harbour to protect shipping from the sandbars that had accumulated, and in $1497 £ 60$ was spent to mend the harbour, but all to no avail. ${ }^{25}$ However the town retained its ancient status as one of the Cinque Ports and staged its ambitious Passion Play, of which records go back to 1387, accompanied by a procession, on a site called Crokhille, in the south of the town and near to St Lawrence's church:

The places from which the players came included members of the Cinque Ports confederation, New Winchelsea, Rye, Hythe, and Folkestone; minstrels also came from Sandwich. Players from small local places on or near Romney Marsh such as Ruckinge and Brookland and Appledore and Wittersham on the River Rother also 'show[ed] their play upon the Crokhil'. ${ }^{26}$

As Draper and Meddens further observe, coastal contacts were consolidated by the play: for example New Romney and Lydd used the opportunity of the get-together to discuss collaborative ventures for trading with France. Production was not regular throughout the whole period in which the play appears in records, and particularly in the sixteenth century the king's leave had to be sought for its revival, but the "playboke" was jealously guarded by civic officials. It saw its final heyday during the reign of Mary Tudor, and it is from that period that the most informative records survive. Also surviving is a processional cross of Continental origin, lost, or more likely buried in the High Street. There is no direct evidence that it played a part in the play or its accompanying procession, but the High Street was paved in 1568, the last year in which the play was performed, and there may well be an "evocative link" between cross and processional route. ${ }^{27}$ We might view this material relic alongside the fragmentary remnants of the opening

\footnotetext{
${ }^{23}$ REED: Kent, edited by Gibson, pp. lix-lx.

${ }^{24}$ Gillian Draper and Frank Meddens, The Sea and the Marsh: the Medieval Cinque Port of New Romney (London and Durham: Pre-Construct Archaeology Monographs, 2009), pp. 16-19. This archaeological study provides readings of the New Romney records that usefully supplement the REED volume, although as an interpretation of dramatic activity, it is less well-informed.

${ }^{25}$ Draper and Meddens, Sea and Marsh, p. 35.

${ }^{26}$ Draper and Meddens, Sea and Marsh, p. 56. Money also changed hands: for example in in 1466-7, 6s. 8d. to the players of Hythe and 22d. for their expenses, and in 1467-68 7s. 11d to the players from Lydd. (Chamberlain's Accounts, REED: Kent, edited by Gibson, p.738)

${ }^{27}$ Draper and Meddens, Sea and Marsh, p.57.
} 
procession that preface N.town Passion Play 1, which the compiler of that manuscript also failed to bury irretrievably.

The New Romney records emphatically confirm the scale of production. As we have seen from internal evidence, the N.Town play was constructed to engage a large audience; here we know that in the fifteenth century crowd control was a major preoccupation for the town because of the influx of people from neighbouring communities, and Gibson makes some calculations that speculate that the audience ran to thousands, on the basis of mid sixteenth-century gate receipts. ${ }^{28}$ This may be an exaggeration, but even a plausible one thousand amounts to a large crowd, probably effectively the whole community including the outlying villages, and possibly some visitors from further afield, including London, with implications for the design of the miseen-scene. It is unsurprising, therefore, to find that by the sixteenth century at New Romney a ‘devisor’ was employed. In 1560 this was Gover Martyn, who was paid $£ 4$ for his services, and a further sum for 'certen necessaryes' he brought from London. ${ }^{29}$ This is not the place in which to enter the debate about whether we should imagine the devisor as working behind the scenes or fully visible on stage, but his existence is both necessary and apparent. ${ }^{30}$ Martyn thus joins the list of those who emerge from the shadows, from Nicholas Cysat of Lucerne, to Coventry's Robert Croo who rewrote some pageants, supplied a hat, and played God, and later in the same city, upholsterer Thomas Massey, who acted as devisor and advocate of the city’s plays just when they were being forceably shut down by Puritan authorities. ${ }^{31}$ The records of what seems to be a similar collaborative enterprise from Maldon in Essex, on the strength of the quantities and cost of raw materials gathered for staging and the numbers of labourers involved, reveal that that town employed Felsted of London, who supplied specialist paints and gunpowder, and had to be boarded in the town for six days. ${ }^{32}$

Returning to New Romney, a detailed account of 1483-6 is labelled as the 'playwarden's'. 33 The playwarden is probably not quite a devisor, but more likely equivalent to

\footnotetext{
${ }^{28}$ REED: Kent, edited by Gibson, p. lx

${ }^{29}$ REED: Kent, edited by Gibson, p.787.

${ }^{30}$ For discussion of the on-stage devisor's role see the essays in Philip Butterworth, ed., The Narrator, the Expositor, and the Prompter in European Medieval Theatre (Turnhout: Brepols, 2007).

${ }^{31}$ For Cysat see The Staging of Religious Drama, edited by Meredith and Tailby, p.52; for Croo and Massey see Coventry Corpus Christi Plays, edited by King and Davidson, pp. 52-3, and p. 33.

${ }^{32}$ Space here does not permit a full exploration of the intersection between Felsted's activities in Maldon and his better-known theatrical work in London; his career is well documented in Meg Twycross, "Felsted of London: Silk Dyer and Theatrical Entrepreneur, Medieval English Theatre, 10:1 (1988), 4-16.

${ }^{33}$ REED: Kent, edited by Gibson, pp. 745-47.
} 
the 'pageant masters' named in the York Mercers' indenture of $1435,{ }^{34}$ and given responsibility for the production and, in particular, the custodianship of its properties. The New Romney playwarden held responsibility for the whole organisation and quality control system of the production. He paid out a lot of money for food and drink. One John is paid for making 'skochynnys', that is shields. These could be costumes for the soldiers at the Crucifixion, but context is everything. Other payments all relate to the setting up of the entire production: mowing the grass, minstrels, boards, shoeing the horse of a bann-crier, and $2 \mathrm{~d}$. for those who 'kept' that is maintained or guarded, the place, thus suggesting that the scutcheons were integral to the whole set, a series of decorative shields or labels for various elements of staging. Payments are made for labour, but also for 'reward', giving a glimpse of the combination of paid labour and volunteer-work as gradually the setting up procedures for a large seasonal, outdoor, community undertaking come into focus. There is careful monitoring of each sum restat in pixide [that remains in the cash-box].

The Chamberlain's accounts of the second play then begin to reveal some detail of the content of the production, ${ }^{35}$ besides payments for 'grass', rosin and paper, cloth, and transport, with a payment to Thomas Bursell, probably a smith, of 5d. 'pro Campanis pro inferno' [for the bells of hell]. The same Thomas receives half this sum for the macaronically expressed 'garnysshynge de heven \& pro le taking down \& pro Clauibus' [for decorating heaven, taking it down, and for nails]. The Last Supper, in N.town a major climax to Passion Play 1, was here part of the second play of the four, possibly its opening scene, as John Humfrey is paid for roasting the paschal lamb at his house. Thomas Taylor received 3s. 4d. for making the tormentors' garments, and William Buckhurst 4d. for their hoods. The Entry into Jerusalem has to occur between the Supper and the tormentors, and there it is, in the payment of a penny for two 'halters for the asse'. Thomas Sedle was paid for six yards of 'Blankett', that is woollen cloth for making gowns for the bishops - by whom we imagine is meant Annas and Caiaphas while there was also a payment for lambs' skins, which we return to later. Thereafter the account moves to list the names of those who have loaned money for the play, followed by a list of money received by the banns-criers. Banns were called in Ivychurch, Folkestone, Hythe, Lydde, and Brookland, where money was collected. The amount of labour, and the quantities of

\footnotetext{
${ }^{34}$ See REED: York, edited by Alexandra F. Johnston and Margaret Rogerson Toronto: Toronto University Press, 1979), pp. 55-56.

${ }^{35}$ REED: Kent, edited by Gibson, pp. 747-50
} 
raw materials, conjure up a production on a scale commensurate with the N.Town text in New Romney at around the same period in the fifteenth century. The play called on a number of organisational and artisanal skills, and with a reach from Sandwich to Winchelsea. This picture is then confirmed by the fuller accounts from the middle of the sixteenth century, during the reign of Mary Tudor.

The New Romney civic government was, from the thirteenth century at least, in the hands of the 'Jurats', whose chief responsibility was to account to the commonalty for its finances, as well as to exercise limited judicial functions. A bailiff and sub-bailiff acted as the Jurats' officers. $^{36}$ The Jurats’ Record Book for 27 December 1555-6 records three recognizances taken before Richard Bunting, the bailiff, by citizens who must each pay the Crown $£ 5$ on the feast of Epiphany as they have undertaken to be the players in the 'stage playe At New Romeny... and have recyvyd players Speches or partes in theseyd playe'. ${ }^{37}$ Where the Maldon records give the names of only two characters, John the Baptist and Christ, on which to build the supposition that theirs was a Passion Play, ${ }^{38}$ these recognizances supply seductively complete lists, as each lists the names of players and the characters they will play. The memoranda go on to promise that if each of the listed actors learns his part before the feast of Pentecost and plays the same, and shows up at New Romney for their rehearsals, then the recognizance shall be void, suggesting that these men are effectively standing surety for the production of the play, with the backing and encouragement of the Crown in an England newly restored to Catholicism.

This sequence of three memoranda provide a wealth of information. The text is being split up into parts, as is familiar to historians of the Shakespearean stage, each actor receiving only his role, bracketed by cues. Those parts include a number of subsidiary characters; not only are there messengers, but the blind man for the miracle on the road to Jerusalem is furnished not only with a boy to lead him, but with parents, further supporting the picture developed above of how the N.Town play works in a large space for a large audience. We have evidence for the doubling of parts: Pilate's messenger and Caiaphas's messenger are played by John Findall, Annas and the second devil by John Plomer, St Philip and the blind man's mother by John Watt, one of the neighbours and one of the Jews by Robert Davy, and the fourth devil and Simon by William Hardyng. And we know that men took on all the female roles: John Crockey was

\footnotetext{
${ }^{36}$ Draper and Meddens, Sea and Marsh, pp.46-47.

${ }^{37}$ REED: Kent, edited by Gibson, pp. 779-82.

${ }^{38}$ Coldewey, “Early Essex Drama”, p. 57.
} 
Annas’s handmaid, John Wallis was Martha, James Christian played mary Magdalen, and Robert Gallyn the Virgin Mary, throwing into question the rather ambiguous entry from 1480 that one Agnes Ford was paid 6s. 8d. 'pro ludo interludij passionis domini' [for the play (or performance) of the interlude of the Lord's Passion]. ${ }^{39}$ Then in a marginal note to the first memorandum we find the information that each of the tormentors has a name, that tips the play from biblical history into the realm of moral allegory. Played by Robert Edolf, Clement Stuppeny, Laurence Stuppeny, Simon Padiam, James Greenaway and John Hollock, they are called Mischance, False at Need, Untrust, Faintheart, Unhap, and Evil Grace, and, moreover, the scribe adds after the name Faintheart 'be me Symon padyam', thereby signing the document. ${ }^{40}$

Another conventional binary is here challenged by the New Romney accounts, and that is the divide between biblical, that is historical, and 'morality' drama, the latter also presenting the fall and redemption of humanity but in the mode of tropological allegory. We might set this slippage into the allegorical mode in a chance-surviving cast list, alongside the recurring anagogical references to Christ's body in the N.Town Passion Plays, and the list of emblematic costumes listed for the lost Coventry Smiths’ play in 1490 which included four jackets for the four tormentors with dice and nails on them, another four for another four tormentors, with damask lilies on them, as well as two jackets of buckram with crowned hammers on them. All bear witness to understandings of the meaning of represented events that iareshared by the producers and consumers of these dramas.That meaning goes beyond narrative history and accords with the commonplaces of vernacular theology that urge their audiences to relive the events of the Passion, to own the burden of human guilt that necessitated those events, and to take comfort from the perpetual spiritual benefits they accorded. The signature 'event' that defines this mode of understanding is the Parliament of Heaven; Christ's Passion is the imperative 'event' that enables the perpetual reconciliation of justice and truth with mercy and peace, the perpetual availability of grace, sacramentally affirmed. This is a fusion to which the eclectic semiotic systems of theatre are particularly well adapted. The words 'mythic' and 'iconic’ are overused in present day culture, yet they accurately describe the apparent

\footnotetext{
${ }^{39}$ REED: Kent, edited by Gibson, pp. 738 and 1183.

${ }^{40}$ REED: Kent, edited by Gibson pp. 738, 745-50, 779-94. Simon Padiam later goes to London on play business, is paid for writing out the play and the parts for the actors. His "chasing staff”, a halberd or bill - more likely than "chafing staff” as read in the REED transcription - is lent, broken and mended.
} 
understanding of the Passion narrative, and the theatrical presentation of that understanding, that the plays under consideration here aspired to.

The real challenge of the New Romney accounts, however, is to work out which episodes are being played. The memoranda do not list the whole cast; notably Christ himself is not mentioned. Perhaps he had to be an ordained priest as is the case in a number of continental religious plays, or perhaps this record observes the same decorum that was unsuccessfully applied in the 1951 Festival of Britain production of the York Cycle, where the actor playing Christ was required to remain anonymous. ${ }^{41}$ The presence of the deity in the play is attested later, when, in 1560-61, 8d. is expended in making 'the first godheddes Coote'. ${ }^{42}$ Christ changed garments from this one worn up to and during the arrest, followed by a second coat made of the lambskins for the Buffeting, then finally replaced by 'di. Dosyn shepeskynnes for ye godheddes coote for the iiijth playe'. ${ }^{43}$ There gaps more convincingly demonstrate that the list of those standing surety is not the same as a whole cast list: we have a second and a fourth devil without a first and a third, let alone Satan himself, and we have someone playing one of the neighbours and one of the Jews, without the rest, and in 1560-61 the previously unrecorded Centurion's horse cast a shoe. The blind man with his attendants, and Lazarus, Mary and Martha, demonstrate that the play extends back to the culminating miracles on Christ's last journey to Jerusalem. The necessary characters for the trial scenes, minus the protagonist himself, are listed, as are the disciples, including Judas and excluding Matthias, for the Last Supper; Malchus’s presence implies an elaborated arrest of Christ, and as would be expected; Simon of Cyrene is there to carry the Cross, but there is no mention of Veronica. But where does John the Baptist, whose coat is made from canvas fetched from Rye and later painted, fit in ${ }^{44}$ He is there in the Maldon accounts too. It seems inherently unlikely that the play included a Baptism, ${ }^{45}$ so he is either, as in N.Town, a prophetic prologue figure, or there to issue from Hell when it is harrowed, but no

\footnotetext{
${ }^{41}$ The Daily Mail makes clear that the decision was at the instigation of the Archbishop of Canterbury, while the Daily Express made it its business to break the actor's cover. See the director, E. Martin Browne's scrapbook, unpublished, in the E. Martin Browne Collection, property of Medieval English Theatre and held in the University of Lancaster.

${ }^{42}$ REED: Kent, edited by Gibson, p. 786.

${ }^{43}$ REED: Kent, edited by Gibson, p. 789.

${ }^{44}$ REED: Kent, edited by Gibson, p. 794.

${ }^{45}$ Gibson understands that the first play was 'a sequence of five scenes mostly unique to the Gospel of John' and covering the ministry of Christ, He includes the Baptism in this sequence, but it seems unlikely for a number of reasons, including the content of the liturgy for the end of Lent and Holy Week from which the Passion narrative is distilled, that the play should reach back to this event, without, for example, including the Temptation. REED: Kent, edited by Gibson, p. lxi
} 
others of the inhabitants of limbo are listed. On the other hand, that the final play had special effects is more than adequately supported by the explosive shopping list ordered up by Gover Martyn that enters the account in 1560-61, ${ }^{46}$ where the Chamberlains record paying for 'brymstone', 'red leade', 'red oker', 'rosset', ‘fflorey', 'vardegrese', and a dozen 'goldskynes' and a dozen sheets of gold foil. There are numerous other enigmatic records that cannot be explored here. ${ }^{47}$ The final account of income and expenditure for 1560-61 allocates responsibilities for the building of stages: Pilate's and the princes', Annas's and the tormentors', the Pharisees', Herod's, Heaven, 'the cave', and hell, which finally gives us some idea of the organisation of the scaffolds in the place. The making of 'the morteys for the iij crosses' completes the scene. ${ }^{48}$

In conclusion, reading these fragmentary witnesses to essentially ephemeral events can assist us to an understanding of the English Passion Play as a distinct genre of early communitybased biblical drama. The ways in which these plays appear to have addressed the occupation of time and space, communication with the audience, and their whole approach to what modern Christian sculptor Antony Gormley has described as art's project of 'domesticating the epic' appears sufficiently distinct in scope, scale, and dramaturgical treatment from the sequential cycles of pageants which dominate popular understanding of 'mystery plays', to merit discussion in their own right. The Records of Early English Drama project has already exposed the binary divide of medieval English drama into mystery and morality plays as inadequate; this essay suggests that in reading those assembled records we attend to the sub-genre of the English Passion Play as another quite distinctive loss to the English theatrical scene.

\author{
Pamela M. King \\ University of Bristol.
}

\footnotetext{
${ }^{46}$ REED: Kent, ed. by Gibson, p.791

${ }^{47}$ For example, the construction of the city of Samaria, although this could be the departure-point for the journey to Jerusalem into which the encounter with the woman at the well may have been compressed, the importation of many wagonloads of 'bowes' (boughs for the entry into Jerusalem, because once 'byrchyn bowes', or bows?), and grass (for strewing under foot as sweet herbs are in Continental processions?), and the payment for digging holes or the play, probably for the crosses. See REED: Kent, ed. by Gibson, pp. 788, 787, 788.

${ }^{48}$ REED: Kent, ed. by Gibson, p. 794.
} 